Mrdjan M. Mladjan ${ }^{1 *}$, Dušan Z. Marković ${ }^{2}$ ${ }^{1}$ EBS Business School, Germany

\title{
Diagrams of Power and Strategic Decision Making: the Case of Strategic Alliances in the Automotive Industry
}

\author{
DOI: 10.7595/management.fon.2019.0015
}

\begin{abstract}
:
Research question: This paper, on the example of strategic alliances in the automotive industry, investigates how diagrams could be useful in studying complex power relationships. Motivation: The relative power of individuals and institutions is a crucial driving force of their interactions. It is however hard to evaluate because the interactions can take place simultaneously or sequentially in different markets or forums. Diagrams of power, that this study introduces, help us abstract the relative power of agents. This enables us to use insights of decision and game theory, especially those from the literature, in strategic decision making under uncertainty (Courtney, Kirkland, \& Viguerie, 1997), to arrive at successful and sustainable solutions. They enable us to view relationships between firms as security dilemmas (Posen, 1993), which can explain why emerging market multinationals (EMMs) treat the acquired companies as strategic partners (Kale, Singh, \& Raman, 2009). Idea: Diagrams of power and security dilemma help us better understand strategic alliances in the automotive industry. Moreover, we believe that diagrams of power could both offer new insights to scholars and represent an intuitive tool for businessmen and policy makers less experienced with advanced mathematical methods. Data: To quantify the power of several automotive producers, we have used selected contemporary data items from their annual reports and the International Organization of Motor Vehicle Manufacturers. Tools: The tool we introduce to better understand power relationships between automotive producers are the diagrams of power. We then apply them to two cases from the industry to better understand the strategic interactions within alliances. Findings: We demonstrate that diagrams of power can help managers define the goals of strategic alliances, minimize the risks of their establishment and management, and recognize the problems and opportunities that arise in strategic partnerships due to security dilemmas, a concept that originated in the study of wars. Diagrams of power enrich the analytical toolkit of the existing literature, enabling faster understanding of the relationship between agents as well as decision making based on more complete information. Contribution: This paper introduces diagrams of power - a tool for study of strategic interactions - and applies the concept of security dilemma to the study of the automotive industry.
\end{abstract}

Keywords: decision making under uncertainty, power relationships, diagrams of power, security dilemma, strategic alliances, automotive industry, emerging market multinationals.

JEL Classification: B40, C73, D74, D81, F21, F23, F60, H12, M16, M21

\section{Introduction}

The relative power of different individuals, companies, organizations, or even nations is one of the key determinants of the dynamics of their relationships. Moreover, given that actions of one side can be perceived as pre-emptive or reactive to the actions of the other side, the changes over time in their relative power can be seen as dynamic games of incomplete information. The insights derived from extracting the most important determinants of interaction to reduce its complexity to such games may occasionally offer an advantage over one's competitors. In order to choose the actions that are most likely to lead to such sustainable equilibria that can be characterized as personal, corporate, or national success, it thus becomes crucial to understand well both the current and the expected future power of oneself vis-à-vis the others. This 
realization allows one to correctly estimate the payoffs to the game in all potential outcomes and so better inform one's decisions on when and how to act. The relative power is however frequently hard to estimate. This is because individuals interact in various spheres of life, firms compete in different markets, and countries cooperate or fight on various fronts.

In this paper, we argue that a way to summarize and better understand the power relationships that surround us is to use a new type of diagrams. We propose to name them diagrams of power. To the best of our knowledge, this is a novel type of Venn-like diagrams to describe power relationships, although variants of the term itself already exist in several other disciplines ${ }^{2}$. To illustrate how they could be used to deepen our understanding of strategic decision making under uncertainty, we apply them to the study of strategic alliances in the global automotive industry. We moreover illustrate that decision making of firms in this context can be perceived as driven by security dilemma, a concept that originates from the realist school of international relations (Herz, 1950; Posen, 1993; Tang, 2009). The concept emphasizes that a build-up of power that one pursues to insure one's own security, because of indistinguishability of defence and offense, may be perceived by others as a potential threat. This could trigger a chain of events that could lead to a conflict even without original aggressive intentions. In cases when one wants to avoid a conflictual scenario it thus becomes crucial to understand the concerns of others and to choose the type and timing of moves that build mutual trust instead. In this paper, we demonstrate how diagrams of power allow us to better understand the interests and concerns of the various agents, and to identify the course of action that can lead to a desired outcome.

Our paper most closely relates to the pioneer work of Shenkar and Arikan (2009) who first called for the use of insights from nation-state to inter-firm alliances suggesting that, among other concepts, security dilemma could become part of shared base for theory development. Our paper builds on this idea and proceeds to show how security dilemma can help us better understand inter-firm alliances, and how diagrams of power can effectively summarise the relationships and options available to firms. In extending the use of the concept of security dilemma from politics to business, it more broadly relates to the literature on competitive wars of attrition between firms (Bulow \& Klemperer, 1999; Takahashi, 2015). In introducing Venn-like diagrams of power, it most closely relates to Brams (1968) who uses arrow-like diagrams of power structures to simplify relational power structures before proceeding to develop a quantitative index measuring the concentration of power in a political system.

This paper also relates to the literature on the motives for the formation of strategic alliances (e.g., Gundolf, Jaouen \& Gast, 2018), to Das and Teng (2000) who view strategic alliances as a tool for gaining strategic intangible resources, and Luo and Tang (2007) who discuss how companies from emerging markets use strategic alliances. Relatedly, Hennart and Zeng (2002) discuss how differences in the culture, politics, and economics of the partners' nations can determine the success of their alliance. More specifically, it relates to the literature on the strategic alliances in the automotive industry: that on the motivation for forming alliances (e.g., Wang, Nguyen \& Nguyen, 2015) and the effect of alliances on industry's development (e.g. Samsunlu \& Akdemir, 2007).

Our paper is also related to Savoiu, Jasko, Dulanovic, Cudanov, and Craciuneanu (2008), who emphasize the importance of new integrative techniques and methods for improving the effectiveness of management. Vojtek (2018) similarly emphasizes the importance of novel techniques that can deal with uncertainty in managing business processes. By proposing a diagrammatic representation of the relative power of agents, our paper enables us to better understand their expected payoffs from various actions and the likely strategic interactions. For this reason, it relates to the business and economics literature on strategic decision making under uncertainty (Courtney, Kirkland, \& Viguerie, 1997). It thus also relates to decision theory (Simon, 1979), game theory and, in particular, dynamic games of incomplete information (Gibbons, 1992; Popovic, Kuzmanovic \& Andric Gusavac, 2012), real options (Trigeorgis, 1996), and real option games of strategic competition (Grenadier, 2000; Aguerrevere, 2003; Baldursson, 1998).

The following chapter introduces diagrams of power and uses them to define and distinguish between several different types of domination. Chapter 3 uses examples from the automotive industry to demonstrate how diagrams of power can be used to first better understand the reasons for the formation of strategic alliances and then to observe the strategic alliance itself as a security dilemma. The final chapter concludes.

\footnotetext{
${ }^{2}$ The term "diagrams of power" was also used by the French philosopher Paul-Michel Foucault but in a very different context, to refer to different forms of power (Foucault 1979; 2004). The phrase "diagrams of power" can also be encountered in various fields of engineering (e.g. Sekine and Beaumont, 2000), while "power diagrams" is another name for the Laguerre-Voronoi diagrams used in computational geometry (Aurenhammer, 1987).
} 


\section{Diagrams of Power in a Multi-Agent Setting}

To be able to better understand the relationships of power between agents of different strength, that also have an ability to form alliances, we propose to use Venn-like diagrams of power. If both agents could hurt, but not fully destroy each other, we represent this as shown in Figure 1, and say that neither agent is dominant. If Agent 1 could not be significantly hurt by Agent 2 and could hurt Agent 2 but not fully defeat it, we represent this as shown in Figure 2, and say that Agent 1 partially dominates Agent 2. Notice that, in Figure 2, Agent 1 is described with a thicker line than Agent 2. If, however, Agent 1 could fully defeat Agent 2, we show this as in Figure 3, and say that Agent 1 fully dominates Agent 2.

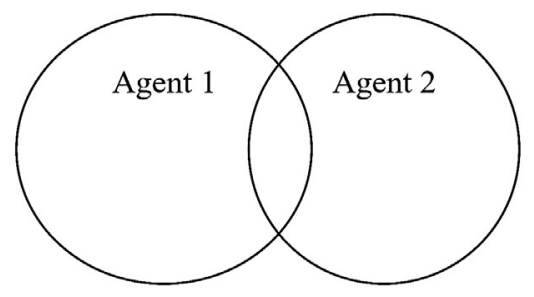

Figure 1: No domination Notes: Authors' original diagram.

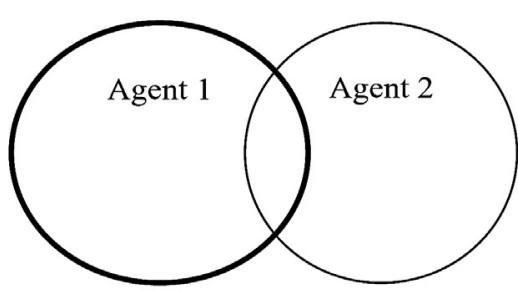

Figure 2: Partial domination Notes: Authors' original diagram.

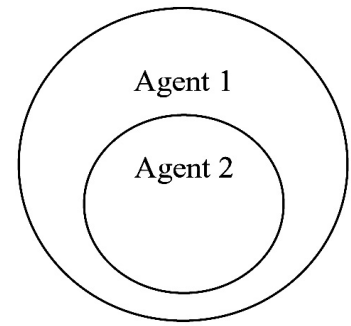

Figure 3: Full domination Notes: Authors' original diagram.

Diagrams of power could also be used to summarize relationships of power that involve more than two agents. Figure 4 illustrates one such multi-agent power relationship. It shows that Agent 1 is fully dominated by Agent 2, which is in turn fully dominated by Agent 3, while Agent 4 fully dominates all. In this case, we say that Agent 4 is absolutely dominant while Agent 2 is relatively dominant (over Agent 1) and Agent 3 is also relatively dominant (over Agent 1 and Agent 2).

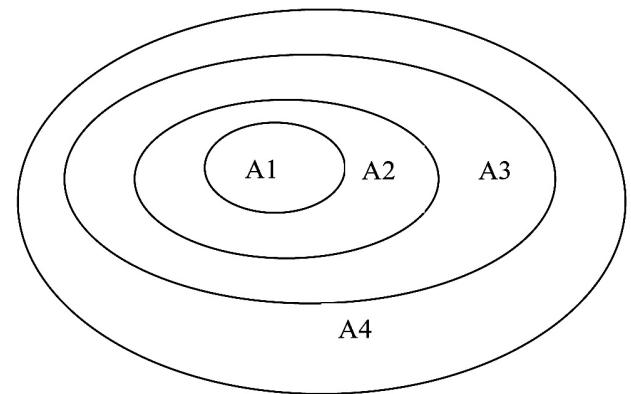

Figure 4: Absolute and relative domination Notes: Authors' original diagram.

\section{Diagrams of Power and Security Dillema in the Study of Strategic Alliances}

Having shown how various types of domination could be represented using diagrams of power, in this chapter we demonstrate that management is one of the academic disciplines in which diagrams of power could be applied in practice. Using examples from the global automotive industry, we first show that 
diagrams of power can be used to better understand the motivation for formation of strategic alliances. We then explain how security dilemma could arise within strategic partnerships and illustrate that diagrams of power could help us understand the problems and identify ways to overcome them. Moreover, we show that a similar type of considerations is causing emerging market multinationals' (EMMs) to treat their acquired targets as equal strategic partners.

\subsection{Diagrams of power and the reasons for creating strategic alliances}

Competitive rivalry has frequently been analysed in economic literature and is considered to be one of the main determinants of industry profitability (Porter, 2008). Severe competition forces companies to expand business operations abroad and to heavily invest in research and development (R\&D). However, given that most companies are not capable of simultaneously achieving both of these goals independently, they resort to acquisitions and the formation of strategic alliances (Barney \& Tong, 2006). Broadly classified, strategic alliances can be motivated by: risk management, creation of new and the additional exploitation of the existing capabilities, and reaction to competitors' actions (Weston, Siu \& Johnson, 1997, p. 417). In this section, we proceed to illustrate each of these motives on the example of the strategic alliance between Renault, Nissan, and Mitsubishi. Moreover, we show how diagrams of power - succinctly depicting the competitive landscape of the industry before and after the alliance was formed - can help us better understand the motivation of these three companies.

The French automotive company Renault and the Japanese automotive company Nissan established a strategic partnership in 1999. In the past, they both had bad experience with strategic partnerships; Renault-Volvo and Nissan-Daimler partnerships resulted in divorces and business failures. Contemporary data of the analysed companies reveal the drivers for making the alliance. In 1999, Nissan's financial situation was critical, the company had not produced profit for eight years. The company posted almost 1 billion net loss in the year (Nissan Motor Corporation, 2001). Due to continuous poor performance corporate debt rose to more than USD 22 billion and the company was on the brink of bankruptcy (Gill, 2012). Overcapacity was the major problem for the company since the production volume had decreased by $20 \%$ cumulatively since 1992 , even though the company had a foothold in both the US and Asian markets (Segrestin, 2005). At the same time, Renault had healthy finances and a high rate of utilization of production plants but was focused and over dependent on the domestic and the western European markets. Understanding that the automotive industry would be consolidated, the two companies decided to form a strategic partnership so as to deal with current and future risks. After Mitsubishi, another Japanese company, joined the alliance in 2017, and the largest auto producer was born. Mitsubishi's market position was weakening and its production dropped by 13.5\% from 2014 to 2016 (Mitsubishi Motors, 2018). In 2016, the company admitted it had rigged fuel efficiency tests for the past 25 years. Due to the scandal the company lost more than $50 \%$ of its market value and recorded 1.7 billion USD net loss. Nissan acquired the largest single stake in the company, about $34 \%$, and help it to avoid bankruptcy.

The diagram of power shown in Figure 5 summarizes the market power relationship in the auto industry before the establishment of the alliance: Renault on the one hand, and Nissan and Mitsubishi on the other, were largely competing in different markets. As "local players", controlling less than $5 \%$ of the global market each, all three were dominated by "global players". The largest two producers at the time were General Motors and Ford, controlling $15 \%$ and $12 \%$ of the global market each (OICA, 2018). While in this environment survival and corporate success would be clear reasons for forming an alliance, we can identify the finer underlying motives in each of the three mentioned categories.

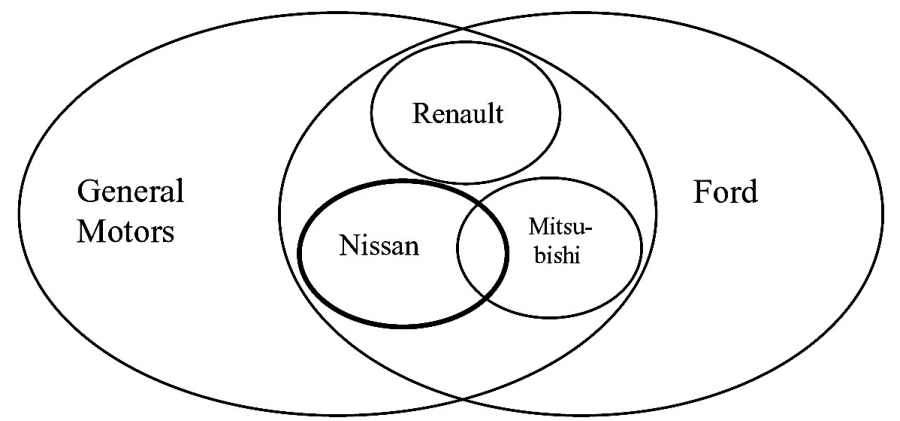

Figure 5: Power relationships before the strategic alliance in 1999 Notes: Authors' original diagram. 
The first motive for the formation of strategic alliances is a proper management of political and business risks. Strategic alliances motivated in this way are frequent in markets characterized by high political risks and inefficient institutions. The probability of asset nationalization and business constrains by local governments are lower when multinational companies (MNCs) embed local partners in their own business network. Undoubtedly, MNCs may have enough knowledge and resources to defeat the local competitors, but they have to be careful about the possible reactions of the local governments. Such reactions can cause serious obstacles to business and even result in termination of business projects abroad. On the other hand, the local governments do not have an interest in preventing the strategic alliances of the local companies with their multinational partners, because cooperation with global industry leaders improves the formers' competitiveness. To explain the afore described situation, we can resort to a simple diagram of power of embedded circles similar to the one shown in Figure 4. The local governments are absolutely dominant, while MNCs relatively dominate the local companies who in turn enjoy the support of their governments; this forces the MNCs to be considerate of their local counterparts. Similar considerations motivated Renault to form an alliance with Nissan, even though it was financially capable of simply acquiring it. What Renault knew is that the Japanese government is not fond of foreign investments, especially in such an important sector, and could create obstacles for the acquisition. By instead forming a strategic partnership with Nissan, Renault managed to both achieve local market presence and avoid a hostile intervention from the Japanese government.

The second motive for strategic alliances is the creation of new capabilities. Companies that try to independently innovate may overcommit resources, or disperse them across too many projects, consequently facing higher business risks and operating costs. This can be avoided by either narrowing the area of research and development (R\&D) efforts or by establishing strategic alliances with key customers, suppliers, or even competitors. Knowledge and capabilities created together with its strategic partners could enable a company to sustain a "no domination" position inside its industry, or even to dominate the non-partner competitors. The complementarity of resources and potential for synergies in creating new capabilities also motivated Renault and Nissan to form an alliance. While Renault had capabilities in R\&D, design and marketing, Nissan was strong in engineering technology. By joining their capabilities they developed a production platform that enabled them to achieve a cost synergy in R\&D, production, logistics and supply. After both Renault's and Nissan's production plants were equipped with the same platform, they could share their production plants and so better manage regional fluctuation in demand. By sharing their research capabilities they also created a new capability to develop electric cars. After joining the strategic alliance, Mitsubishi accepted the same platform and brought in additional capabilities in the production of crossovers, pickups, and hybrid vehicles. Due to sharing of both risks and costs, the Renault-Nissan-Mitsubishi alliance emerged as one of the leaders in the production of green autos, controlling more than $10 \%$ of this small but growing market segment.

The third and last motive for forming a strategic alliance is the protection from aggressive actions of incumbents and from new players in the industry. The incumbents and late followers sometimes create disruptive innovations which cause industry reshaping, or even termination, and can lead to defeat of reactive competitors (Downes \& Nunes, 2013). Disruptors' innovations could reshape both industry structure and customer preferences. Because the traditional competitors with considerable sunk costs may frequently not have enough resources and adequate competencies to compete against the disruptors, they could be forced to unite their efforts and resources, similar to that what happened to Renault and Nissan. Before they formed a strategic alliance, they focused their marketing efforts on their respective domestic regions, Europe and Asia. They did not have the capabilities and resources to significantly increase their R\&D investment and expand operations outside of these regions. In turn, they faced the risk of being squeezed out and overrun by industry leaders with global market presence, such as Toyota and Volkswagen. This led Renault and Nissan to join their efforts in protecting themselves from the aggressive leaders. They had to create a joint business vision and coordinate business activities so as to compete as a single entity in the global market. To overcome the differences in language and culture, they chose English as the official language of the alliance. They were also committed to preserving partners' business autonomy and to holding stakes in each other, with the aim of creating trust and strengthening their business relationship.

The diagram of power shown in Figure 6 summarizes the market power relationship in the auto industry after the establishment of the alliance. The increase in power of Renault, Nissan, and Mitsubishi after formation of the alliance, evident when comparing Figure 6 to Figure 5, demonstrates the benefits of the alliance. While Renault and Nissan were originally smaller players in the industry, forming a strategic alliance allowed them to challenge the global leaders. Moreover, from 1999 to 2016, their combined global market share increased from 8.6 to 10.7 percent, in spite of the entry of new competitors (OICA, 2018). After their alliance was further strengthened by Mitsubishi joining in 2017, the triple alliance controlled $12 \%$ of the global market, placing them on an equal footing with the two contemporary global leaders, Toyota and Volkswagen, which controlled around $11 \%$ of the global market each, as shown in Figure 6. 


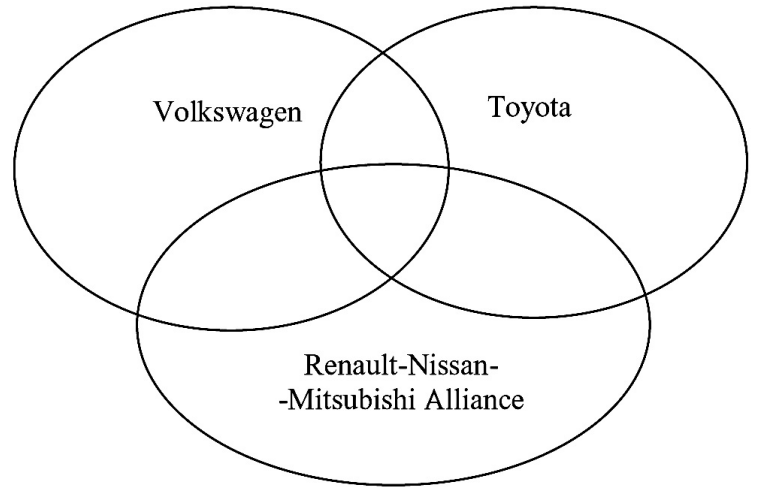

Figure 6: Power relationships after the strategic alliance in 2017 Notes: Authors' original diagram.

\subsection{Strategic Alliance as a Security Dilemma}

While thus far we explained how strategic alliances can be used to gain a competitive advantage, we now proceed to illustrate how such alliances could present the partners themselves with a security dilemma. Such dilemmas are an additional aspect of alliances that lend themselves to a better description of using diagrams of power. They arise because the partners' access to a company's strategic intangible resources could be abused. The two strongly connected processes of which the alliances comprise, value creation and value division, are frequently described separately, but diagrams of power allow us to analyse them simultaneously. This is illustrated in Figure 7. If firms A, B, and C form an alliance, they could be strong together, just like Renault, Nissan and Mitsubishi in Figure 6. Their overlap, however, shows that, if their cooperation breaks, they could potentially endanger each other by using the former access to partners' strategic resources to better compete against each other. Note moreover that the partners' circles overlap in a diagram of power even if they operate in different markets. This holds because a company could hurt a former partner by offering the information collected during the partnership to its direct competitors, or because the knowledge acquired through the partnership could allow it to enter the home market of its former partner.

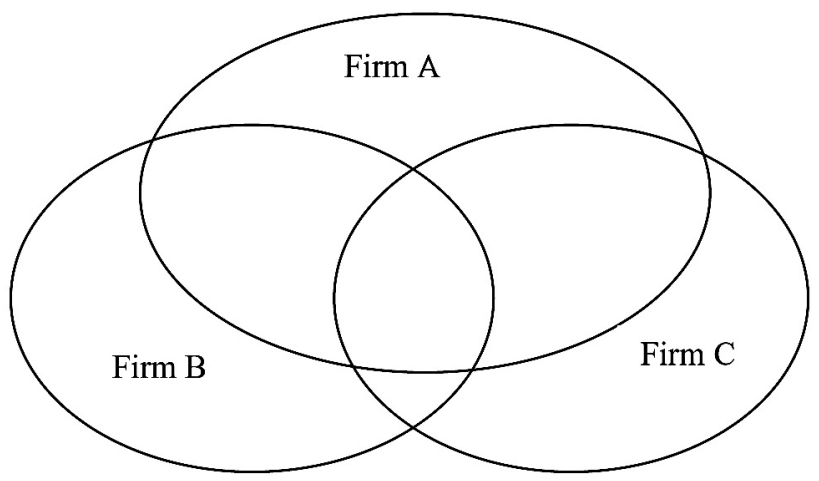

Figure 7: Security dilemma within a strategic alliance Notes: Authors' original diagram.

In case both sides in a partnership are aware of the risk that a partner could use the knowledge acquired from the alliance to turn, or turn back, into a competitor, a possible outcome could be that both attempt to acquire the desired knowledge as soon as possible and leave the partnership (Ireland, Hitt \& Vaidyanatah, 2002; Haisu, Chengli, Xu \& Malter, 2010). It is thus evident that the prospect of such a "learning race" could create a security dilemma within a strategic alliance. The stronger partner could use the alliance to gain knowledge about the business model, technology, and customer relations of the weaker partner, which could in turn make the takeover and the management of the post-acquisition process easier (Porrini, 2004, Yang, Zhiang \& Peng, 2011).

Aware that the uncertainty within partnerships could cause its members to focus on achieving short-term goals at the expense of the long-term ones, the members of the alliance may look for ways to instead reduce the relationship risk and ultimately prevent such a development. The perceived relationship risk itself is in turn determined by written agreements, reputation of the partner, and trust-building measures (Xu, Mei, 
Shanzing, Yongchuan \& Feifei, 2013). Given the dynamic nature of the business environment, formal and detailed agreements cannot however fully protect the partners, while they can limit the efficiency of doing business. Another important factor limiting the likelihood a partner may cheat is his reputation (Baughn, Denekamp, Stevens \& Osborn, 1997; Schilke \& Cook, 2013). Nevertheless, relying solely on reputation may not be enough to protect a strategic partnership. For this reason, companies frequently opt for trust-building measures as a way to manage and limit the relationship risk. A partner's previous reputation represents an initial input in the process of building trust. Trust, as a "soft" element of strategic partnership, is then further built through phases of negotiation, agreeing to specified actions, and honouring one's promises, which also further develops one's reputation (Boersma, Buckley \& Ghauri, 2003). Trust contributes to an easier exchange of resources within a partnership which affects the improvement of the partners' performance (Das \& Teng, 2001; Costa e Silva, Bradley \& Sousa, 2012). Some research however shows that improved performance increases trust, while the effect of trust on performance is not as strong (Mohr \& Puck, 2013). How the initial reputation and its further development through the trust-building process can deter a firm from abusing the access to partners' strategic resources is shown in Figure 8. While the potential predator partner partially dominates the vulnerable partner, corporate ethical norms, strengthening the potential predator firm if honoured (in "carrot" role), could also hurt its future if breached (in "stick" role). If the dominant partner decides to act as predator towards the vulnerable partner, his business reputation will be tarnished. Due to damaged reputation, forming new strategic alliance in the future will become costly, inefficient, or impossible. If the dominant partner instead decides to respect the corporate ethical norms, this will endow him with an intangible asset - reputation - which he could use as an input in future strategic alliances.

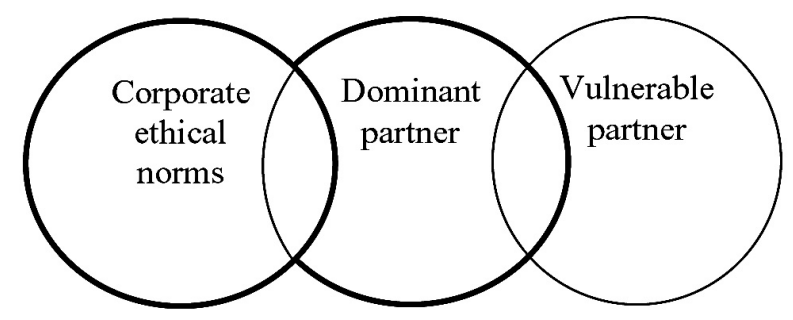

Figure 8: The power of corporate ethical norms in preventing the abuse of a partnership Notes: Authors' original diagram.

A similar security dilemma is identified in cross-border acquisitions of EMMs. Many recent studies that analysed EMMs argued their motives to internationalize business are different from those of MNCs from developed economies (Chattopadhya, Batra \& Ozsomer, 2012; Mathews, 2006; Rugman, 2009). They go abroad to acquire the missing intangible resources (Luo \& Tang, 2007) and accept the risk of cross-border acquisitions to overcome their late followers' disadvantage in the global market (Markovic, Rakita \& Filipovic, 2015). The main challenges for EMMs are how to retain key managers and employees, and how to preserve brand image and relationships with stakeholders in the post-acquisition period. They use a unique restructuring strategy to achieve that aim. The acquired companies are treated like partners in a strategic alliance because synergies originate from complementarities of resources rather than economies of scale (Kumar, 2009; Kale, Singh \& Raman, 2009). Targets' management teams are retained and given independence. Such a trust-building and long-term oriented approach assures a smooth transition and preserves and eases the sharing of strategic resources, thus resulting in benefits from the current acquisition. Moreover, it improves the acquirer's reputation, enabling future cross-border acquisitions that add further value. The acquisition of Swedish Volvo by the Chinese car producer Geely can be seen as an example of such a partnering approach. It is illustrated in the diagram of power presented in Figure 9. It shows how respect for Volvo's autonomy could strengthen Geely if respected, as if Geely is forming an alliance with it, or weaken Geely if disrespected, as if it is a competitor who partially dominates Geely. In reality, Geely took the former approach, respecting Volvo's autonomy.

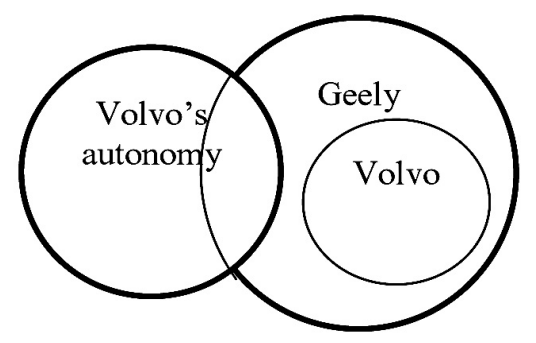

Figure 9: The power of the respect for target's autonomy to strengthen or weaken the acquirer Notes: Authors' original diagram. 
Prior to the acquisition, Geely's image was very different from that of Volvo. It was a producer of low-cost vehicles and completely depended on domestic market. But financially, it was strong: it earned 3.23 billion USD and had a profit margin of more than 7\% in 2010. On the other hand, Volvo was Ford's subsidiary with a strong brand associated to safe cars and innovative capabilities. Despite that the company suffered 650 billion USD net loss in 2010. Its sales dropped by more than $20 \%$ compared to three years before, at the onset of the Great Recession (Markovic, Acimovic \& Mijuskovic, 2016). The new owner made only small changes in the target's management team, preserved Volvo's identity and autonomy, and provided ample financial support. Gradually developed trust resulted in a strong commitment of both parties to share technology achievements, marketing, and management knowledge. Volvo' successful integration improved Geely's reputation as an acquirer and made easier the acquisition of two British firms: the maker of sports cars Lotus and the electric-vehicle startup Emerald Automotive. The acquisition approach proved to be successful due to smooth sharing of resources. Geely sold more than 1.5 million vehicles, earned almost 16 billion USD and generated 1.9 billion USD profit in 2018 (Geely Auto, 2018). At the same time Volvo sold almost 650 thousand vehicles, earned 29 billion USD and generated 1.1 billion USD profit (Volvo Cars, 2018).

\section{Conclusions and Future Research}

In this paper, we introduced diagrams of power into use. We first presented how these Venn-like diagrams can help us summarize relative power of various agents vis-à-vis each other, the options available to each of the agents, and differentiated between different types of domination: partial, full, relative, and absolute. We believe that diagrams of power are an intuitive tool that could offer new insights to scholars, businessman, and policy makers. They could help analyze motives, interests, and risks affecting different agents, and identify actions that result in improvement of their performance. To illustrate how they could serve to better understand complex power relationships and inform strategic decision making, we used the example of strategic alliances in the automotive industry. Applied to the case of the alliance between Renault, Nissan, and Mitsubishi, diagrams of power helped us identify the main reasons for the formation of strategic alliances, and the ways to establish and manage relationships with partners. We then proceeded to argue that interactions within strategic alliances could present individual firms with a security dilemma. Using the example of the acquisition of Swedish Volvo by Chinese Geely, we illustrated how diagrams of power could be used to identify security dilemmas in relationships between firms, and how the latter can explain the way EMMs treat their partners. While Shenkar and Arikan (2009) first suggested that security dilemma, a concept that originated in the study of international relations, could also be applied to the study of firms, our paper is, to the best of our knowledge, the first one that presents one such application. Diagrams of power made it easier to spot the analogy in relationships between nations and between firms, facilitating the application of security dilemma to business interactions.

The avenues for future applications could relate to the study of strategic interactions both in business and in other disciplines. Firstly, diagrams of power allow us to clearly observe the possible alliance-forming patterns and indicate the directions for the most effective actions. They could thus be used to better understand even the aggressive moves that are not based on a security dilemma, be it in business, politics, or elsewhere. By expanding the concept of security dilemma, a more general concept of dilemma over power could be used to understand any actions that attempt to achieve or prevent changes in relative power. In other words, any potential change in diagrams of power could be a motivator for actions based on such a dilemma.

Secondly, diagrams of power could in the future be used to understand strategic interactions in a number of other contexts. They could, for instance, be used to understand the interactions of different political parties, where the "area" they cover may be different political ideas for which they stand. They could also be used to inform crisis management in real wars. In a similar vein, but in a different discipline, diagrams of power could serve to better understand, and potentially prevent, competitive wars of attrition in business. More broadly, the relative power of firms that compete in different markets - in which decisions on successive investments in R\&D and production capacity, decisions on output, and on price, take the form of any real option game - could be represented using diagrams of power. Such diagrams may be able to serve as an additional tool for scholars of business games. Moreover, they should also be able to summarize the insights obtained through game-theoretical research, but in a form which could more easily be communicated to educators and students who, although less familiar with advanced game theory, could benefit from its findings. 
Acknowledgements

One of the authors developed diagrams of power in his final paper written within the graduate class 17.582 Civil War taught by Professor Roger Petersen at the Massachusetts Institute of Technology. We are thankful to Professor Petersen for his dedication to his students, his encouragement and advice. We are also very thankful to the referees and the editorial team of "Management: Journal of Sustainable Business and Management Solutions in Emerging Economies" who provided valuable suggestions for improving the manuscript. All remaining errors are however ours.

\section{REFERENCES}

[1] Aguerrevere, F. L. (2003). Equilibrium investment strategies and output price behavior: real options approach. Review of Financial Studies, 16(4), 1239-1272. DOI: 10.1093/rfs/hhg041

[2] Aurenhammer, F. (1987). Power diagrams: properties, algorithms and applications. SIAM Journal on Computing, 16(1): 78-96. DOI:10.1137/0216006

[3] Baldursson, F.M. (1998). Irreversible investment under uncertainty in oligopoly. Journal of Economic Dynamics and Control, 22(4), 627-644. DOI: 10.1016/S0165-1889(97)00070-5

[4] Barney, J. \& Tong, W. T. (2006). Building versus acquiring resources. In A. Ghobadian, N. O'Regan, D. Galler \& H. Viney (Eds.), Strategy and performance achieving competitive advantage in the global marketplace (pp. 57-81). London, England: Palgrave Macmillan.

[5] Baughn, C. C., Denekamp, G. J., Stevens, H. J., \& Osborn, N. R. (1997). Protecting Intellectual capital in international alliances. Journal of World Business, 32(2), 103-117. DOI: 10.1016/S10909516(97)90002-X

[6] Boersma F. M., Buckley, J. P. \& Ghauri, N. P. (2003). Trust in international joint ventures. Journal of Business Research, 56(12), 1031-1042. DOI: 10.1016/S0148-2963(01)00315-0

[7] Brams, S. J. (1968). Measuring the Concentration of Power in Political Systems. American Political Science Review, 62(2): 461-475. DOI: 10.2307/1952941

[8] Bulow, J. I., \& Klemperer, P. (1999). The generalized war of attrition. American Economic Review, 89(1), 175-189. DOI: 10.1257/aer.89.1.175

[9] Chattopadhyay, A., Batra, R., \& Ozsomer, A. (2012). The new emerging market multinationals: Four strategies for disrupting markets and building brands. New York, USA: McGraw Hill.

[10] Costa e Silva, S., Bradley, F. \& Sousa, M.P.C. (2012). Empirical test of the trust - performance link in an international alliances context. International Business Review, 21(2), 293-306. DOI: 10.1016/j.ibusrev.2011.03.006

[11] Courtney, H., Kirkland, J., \& Viguerie, P. (1997). Strategy under uncertainty. Harvard Business Review, 85(6), 66-81.

[12] Das, T.K. \& Teng, B.S. (2000). A Resources - based theory of strategic alliances. Journal of Management, 26(1), 31 - 61. DOI: 10.1016/S0149-2063(99)00037-9

[13] Das, T.K., \& Teng, B.S. (2001). Trust, control and risk in strategic alliances: an integrated framework. Organization Studies, 22(2), 251 - 283. DOI: 10.1177/0170840601222004

[14] Downes, L., \& Nunes, F. P. (2013). Big bang disruption, Harvard Business Review. 90(3), 44 -56.

[15] Foucault, M. (1979). Discipline and Punish: The Birth of the Prison. New York: Vintage.

[16] Foucault, M. (2004). Sécurité, Territoire, Population - Cours au Collège de France, 1977-1978, Paris: Seuil/Gallimard.

[17] Geely Auto (2018). Annual Report. Retrieved from http://global.geely.com

[18] Gibbons, R. (1992). Game theory for applied economists. Princeton, New Jersey: Princeton University Press.

[19] Gill, C. (2012). The Role of Leadership in Successful International Mergers and Acquisitions: Why Renault - Nissan Succeeded and DaimlerChrysler - Mitsubishi Failed. Human Resource Management, 51(3): 433-456. DOI: $10.1002 / \mathrm{hrm} .21475$

[20] Grenadier, S. (2000). Game choices: The intersection of real options and game theory. London, England: Risk Books.

[21] Gundolf, K., Jaouen, A., \& Gast, J. (2018). Motives for Strategic Alliances in Cultural and Creative Industries. Creativity and Innovation Management, 27(2), 148-160. DOI: 10.1111/caim.12255:

[22] Haisu, Z., Chengli, S., Xu, J. \& Malter, A. J. (2010). Managing Knowledge for Innovation: The Role of Cooperation, Competition, and Alliance Nationality. Journal of International Marketing, 18(4), 74-94. DOI: $10.1509 / j i m k .18 .4 .74$

[23] Hennart, J. \& Zeng, M. (2002). Cross - cultural differences and joint venture longevity. Journal of International Business Studies, 33(4), 699 - 716. DOI: 10.1057/palgrave.jibs.8491040

[24] Herz, J. H. (1950). Idealist internationalism and the security dilemma. World Politics, 2(2), 157-80. DOI: $10.2307 / 2009187$ 
[25] Ireland, R. D., Hitt, A. M., \& Vaidyanath, D. (2002). Alliance management as a source of competitive advantage. Journal of Management, 22(3), 413-446. DOI: 10.1016/S0149-2063(02)00134-4

[26] Kale, P., Singh, H., \& Raman, A. P. (2009). Don't integrate your acquisitions, partner with them. Harvard Business Review, 87(12), 109-115.

[27] Kumar, N. (2009). How emerging giants are rewriting the rules of M\&A. Harvard Business Review. 87(5), $115-121$.

[28] Luo, Y. \& Tang, R.L. (2007). International expansion of emerging market enterprises: a springboard perspective. Journal of International Business Studies, 38(4), 481 - 491. DOI: $10.1057 /$ palgrave.jibs.8400275

[29] Markovic, D., Rakita, B. \& Filipovic, D. (2015). Strategic importance of cross - border acquisitions for emerging market multinationals. In V.R. Ivona, P. Najla \& J. Lara (Eds.), Neostrategic Management (pp. 189-201). New York, USA: Springer.

[30] Markovic, D., Acimovic, S. \& Mijuskovic, V. (2016). Sticanje znanja putem internacionalizacije poslovanja kod kasnih sledbenika u auto industriji. Marketing, 47(4): 267-277. DOI: 10.5937/markt1604267M

[31] Mathews, A. J. (2006). Dragon multinationals: New players in 21st century globalization. Asia Pacific Journal of Management, 23(1), 5-23. DOI: 10.1007/s10490-006-6113-0

[32] Mitsubishi Motors (2018). Annual Report. Retrieved from https://www.mitsubishi-motors.com

[33] Mohr, T.A., \& Puck, J. (2013). Revisiting the trust-performance link in strategic alliances, Management International Review. 53(2), 269 - 289. DOI: 10.1007/s11575-012-0145-0

[34] Nissan Motor Corporation. (2001). Annual Report. Retrieved from https://www.nissan-global.com

[35] OICA (Organisation Internationale des Constructeurs d'Automobiles) (2018). Production Statistics. Retrieved from http://www.oica.net/

[36] Popovic, M., Kuzmanovic, M. \& Andric Gusavac, B. (2012). The agency dilemma: information asymmetry in the "principal-agent" problem. Management: Journal for Theory and Practice Management, 62, 13-21. DOI: 10.7595/management.fon.2011.0005

[37] Porrini, P. (2004). Can a previous alliance between an acquirer and a target affect acquisition performance? Journal of Management, 30(4), 545-562. DOI: 10.1016/j.jm.2004.02.003

[38] Porter, E. M. (2008). The five competitive forces that shape strategy. Harvard Business Review, 86(1), 79-93.

[39] Posen, B. R. (1993). The security dilemma and ethnic conflict. Survival, 35(1), 27-47. DOI: $10.1080 / 00396339308442672$

[40] Rugman, M. A. (2009). Theoretical aspects of MNCs from emerging economies. In R. Ramamurti \& V. J. Singh (Eds.), Emerging multinationals in emerging markets (pp. 42-63). Cambridge, England: Cambridge University Press.

[41] Samsunlu, A. \& Akdemir, A. (2007). The Effect of Strategic Alliances on the Development of Automotive Industry: The Case of Turkey. Journal of Global Strategic Management, 1(1), 124-132. DOI: 10.20460/JGSM.2007118721

[42] Savoiu, G., Jasko, O., Dulanovic, Z., Cudanov, M. \& Craciuneanu, V. (2008). The value of general methods, quantitative techniques and management models in professionalizing management. Management, 49(50), 7-11.

[43] Schilke, O. \& Cook, S.K. (2013). Source of Alliance Partner Trustworthiness: Integrating Calculative and Relational Perspective.Strategic Management Journal, 36(2), 276-297. DOI: 10.1002/smj.2208

[44] Segrestin, B. (2005). Preparing to Explore: The Renault - Nissan Alliance as a Forerunner of New Cooperative Patterns. Research Policy, 34(5): 657-672. DOI: 10.1016/j.respol.2005.02.006

[45] Sekine, H. \& P. Beaumont. (2000). On a simple power law for macroscopic crack propagation rate due to stress-corrosion cracking in unidirectional GFRP composites. Materials Science and Engineering, 285 (1-2), 298-302. DOI: 10.1016/S0921-5093(00)00651-1

[46] Shenkar, O. \& Arikan, I. (2009). Business as International Politics: Drawing Insights from Nation-State to Inter-Firm Alliances. Business and Politics, 11(4), 1-31. DOI: 10.2202/1469-3569.1241

[47] Simon, H. A. (1979). Rational decision making in business organizations. American Economic Review, 69(4), 493-513.

[48] Takahashi, Y. (2015). Estimating a War of Attrition: The Case of the US Movie Theatre Industry, American Economic Review, 105 (7), 2204-2241. DOI: 10.1257/aer.20110701

[49] Tang, S. (2009). The Security Dilemma: A Conceptual Analysis. Security Studies, 18(3), 587-623. DOI:

[50] Trigeorgis, L. (1996). Real Options: Managerial Flexibility and Strategy in Resource Allocation. Cambridge, Massachusetts: The MIT Press.

[51] Vojtek, N. D. (2018). Managing business processes using soft computing techniques - a literature review. Management: Journal of Sustainable Business and Management Solutions in Emerging Economies, 23(1), 63-71. DOI: 10.7595/management.fon.2017.0023

[52] Volvo Cars (2018). Annual Report. Retrieved from https://investors.volvocars.com 
[53] Wang, N., Nguyen, T., \& Nguyen, N. (2015). Strategic Alliance Decision-making for the Auto Industry base on an Integrate DEA and $\mathrm{GM}(1,1)$ Approach. International Journal of Suply and Operation Managements, 2(3), 856-870. DOI: 10.22034/2015.3.03

[54] Weston, F., Siu, J., \& Johnson, B. (1997). Takeovers, Restructuring and Corporate Governance. New York, USA: Prentice Hall.

[55] Xu, J., Mei, L., Shanzing, G., Yongchuan, B. \& Feifei, J. (2013). Managing Knowledge Leaking in Strategic Alliances: The Effects of Trust and Formal Contracts. Industrial Marketing Management, 42(6), 983-991. DOI: 10.1016/j.indmarman.2013.03.013

[56] Yang, H., Zhiang, J. L. \& Peng, M. W. (2011). Behind acquisitions of alliance partners: Exploratory learning and network embeddedness. Academy of Management Journal, 54(5), 1069-1080. DOI: 10.5465/amj.2007.0767

Received: 2018-04-04

Revisions requested: 2018-09-24

Revised: 2019-07-23 (2 times)

Accepted: 2019-08-06

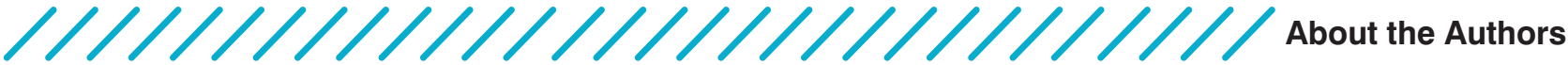

\section{Mrdjan M. Mladjan \\ EBS Business School, Germany mrdjan.mladjan@ebs.edu}

Mrdjan Mladjan received his PhD in Economics at the Universitat Pompeu Fabra. During his PhD studies he was a visiting scholar at the UCLA Anderson School of Management. $\mathrm{He}$ holds a BSc in Economics degree from the Massachusetts Institute of Technology. Mrdjan's research is characterized by interdisciplinarity at the intersection of finance, economics, history, and management.

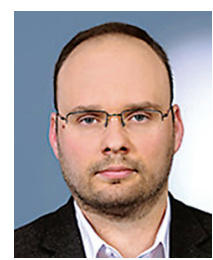

Dušan Z. Marković University of Belgrade, Faculty of Economics, Serbia dusanm@ekof.bg.ac.rs

Dušan Marković is Associate Professor at the Faculty of Economics, Belgrade University, where he also received his PhD in Business. He has published in the areas of Cross-border Acquisitions, Strategic Alliances, Emerging Market Multinationals and

Business Strategies in the Auto Industry. Marković has rich practical experience in capital and asset valuation, financial due diligence, business and financial restructuring, and has previously worked as financial advisor for Grant Thornton Serbia. 